\title{
Lazar Nikolov, Concerto pour violon
}

\section{(2) OpenEdition}

\section{Journals}

Édition électronique

URL : https://journals.openedition.org/etudesbalkaniques/277

ISSN : 2102-5525

\section{Éditeur}

Association Pierre Belon

\section{Édition imprimée}

Date de publication : 1 janvier 2006

ISBN : 978-2-910-86006-6

ISSN : $1260-2116$

\section{Référence électronique}

"Lazar Nikolov, Concerto pour violon », Études balkaniques [En ligne], 13 | 2006, mis en ligne le 01 septembre 2009, consulté le 21 juin 2021. URL : http://journals.openedition.org/etudesbalkaniques/ 277

Ce document a été généré automatiquement le 21 juin 2021.

Tous droits réservés 


\section{Lazar Nikolov, Concerto pour violon}

1 Lazar Nikolov, Concerto pour violon,

Premier mouvement.

Avec Georgi Bliznev au violon et le Nouvel Orchestre Symphonique de Sofia, dirigé par Rossen Milanov.

3. $1^{\text {er }}$ mouvement 